\title{
Review \\ Bench-to-bedside review: Developmental influences on the mechanisms, treatment and outcomes of cardiovascular dysfunction in neonatal versus adult sepsis
}

\author{
Wendy A Luce ${ }^{1}$, Timothy M Hoffman² and John Anthony Bauer ${ }^{1,2}$ \\ 1Division of Neonatology, Center for Cardiovascular Medicine, Columbus Children's Research Institute, Columbus Children's Hospital, \\ 700 Children's Drive, Columbus, OH 43205, USA \\ 2Division of Cardiology and Cardiac Critical Care, Center for Cardiovascular Medicine, Columbus Children's Research Institute, \\ Columbus Children's Hospital, Columbus, $\mathrm{OH} 43205$, USA
}

Corresponding author: Wendy A Luce, lucew@chi.osu.edu

Published: 24 September 2007

Critical Care 2007, 11:228 (doi:10.1186/cc6091)

This article is online at http://ccforum.com/content/11/5/228

(c) 2007 BioMed Central Ltd

\begin{abstract}
Sepsis is a significant cause of morbidity and mortality in neonates and adults, and the mortality rate doubles in patients who develop cardiovascular dysfunction and septic shock. Sepsis is especially devastating in the neonatal population, as it is one of the leading causes of death for hospitalized infants. In the neonate, there are multiple developmental alterations in both the response to pathogens and the response to treatment that distinguish this age group from adults. Differences in innate immunity and cytokine response may predispose neonates to the harmful effects of proinflammatory cytokines and oxidative stress, leading to severe organ dysfunction and sequelae during infection and inflammation. Underlying differences in cardiovascular anatomy, function and response to treatment may further alter the neonate's response to pathogen exposure. Unlike adults, little is known about the cardiovascular response to sepsis in the neonate. In addition, recent research has demonstrated that the mechanisms, inflammatory response, response to treatment and outcome of neonatal sepsis vary not only from that of adults, but vary among neonates based on gestational age. The goal of the present article is to review key pathophysiologic aspects of sepsis-related cardiovascular dysfunction, with an emphasis on defining known differences between adult and neonatal populations. Investigations of these relationships may ultimately lead to 'neonate-specific' therapeutic strategies for this devastating and costly medical problem.
\end{abstract}

\section{Introduction}

Sepsis is a significant cause of morbidity and mortality in neonates and adults, and the mortality rate from sepsis doubles in patients who develop cardiovascular dysfunction and septic shock [1]. Annual combined deaths from sepsis of patients of all ages equal the number of deaths from myocardial infarction [2], and 7\% of all childhood deaths result from sepsis alone [3]. Sepsis is especially devastating in the neonatal population, as it is responsible for $45 \%$ of late deaths in the neonatal intensive care unit, making it one of the leading causes of death for hospitalized infants [4].

The incidence of sepsis is age-related, and is highest in infants $(5.3 / 1,000)$ and the elderly over 65 years of age $(26.2 / 1,000)$ [2]. Although the incidence is highest in the elderly, both the intensive care unit admission rates $(58.5 \%$ versus $40 \%)$ and the average costs $(\$ 54,300$ versus $\$ 14,600)$ are higher in infants [2]. Twenty-one percent of very low birthweight infants will develop at least one episode of culture-proven bloodstream sepsis after the first 3 days of life [5], and the septic episode will probably be more severe than in adults [3]. In very low birthweight infants, sepsis increases the hospital stay by $30 \%$ and increases mortality 2.5 times [5].

Unlike adults, little is known about the cardiovascular response to sepsis in the neonate. Baseline neonatal cardiovascular function has not been well defined, and studies of inotrope use to treat hypotension in neonates have failed to show any improvement in short-term or long-term clinical outcomes [6]. In addition, recent research has demonstrated that the clinical presentation, mechanisms, inflammatory response, response to treatment and outcome of neonatal sepsis vary not only from that of adults, but vary among neonates based on gestational age. The goal of the present article is to review key pathophysiologic aspects of sepsisrelated cardiovascular dysfunction, with an emphasis on defining known differences between adult and neonatal populations. The potential impact of these differences on therapeutic strategies is also discussed.

$\mathrm{IL}=$ interleukin; $\mathrm{LPS}=$ lipopolysaccharide; $\mathrm{TNF}=$ tissue necrosis factor. 


\section{Innate immunity/inflammatory response}

Underlying the differences in neonatal and adult sepsis are alterations in the developing immune system. These differences include innate and acquired immunity, immune cell numbers and function, cytokine elaboration and the inflammatory response.

The influence of perinatal factors on the development and response to sepsis is unique to newborns. Challenges to the maternal immune system before and during pregnancy have been associated with modulation of the neonatal immune response, and this modulation occurs in both humoral and cell-mediated immunity [7]. Although proinflammatory cytokines such as TNF $\alpha, I L-1 \beta$ and IL- 6 have not been shown to cross the human term placenta [8], certain immunoglobulins and lymphoid cells can cross the placenta and change fetal and postnatal immune development [7]. The transplacental transfer of immunoglobulins, however, does not occur until 32 weeks gestation [9], leading to a relative immune deficiency in extremely premature infants. Labor of any duration may be immunologically beneficial to the neonate, with improved neutrophil survival and lipopolysaccharide (LPS) responsiveness [10]. Labor itself is a mild proinflammatory state and has been associated with delayed neutrophil apoptosis, fetal leukocytosis and elevation of the systemic neutrophil count when compared with cesarean section without labor [10]. In addition, respiratory burst, CD11b/CD18 and IL-8 receptors have all been shown to be increased after vaginal delivery in comparison with cesarean section [11].

\section{Cytokines}

Severe infection can induce the systemic inflammatory response syndrome and can lead to the development of septic shock, which is associated with elevated levels of proinflammatory cytokines including $\mathrm{IL}-1 \beta, \mathrm{IL}-6, \mathrm{IL}-8$ and TNF $\alpha$ [12]. LPS is a cell wall component of Gram-negative bacteria, and is the main endotoxin implicated in the initiation of the proinflammatory response [13]. If this extreme inflammatory response is not counterbalanced by a competent compensatory anti-inflammatory response syndrome, the resultant exaggerated inflammatory response leads to increased morbidity and mortality during sepsis [14]. The concentration of proinflammatory cytokines is higher in patients with septic shock than in those with severe sepsis, and elevated levels of IL-1 $\beta$, IL- 6 and IL- 8 are associated with an increase in early mortality ( $<48$ hours) [12]. Sepsis also has the potential to develop into a bimodal disease initially characterized by a proinflammatory state and progressing to a state of immune suppression and immunoparalysis $[15,16]$, which is related to increased production of IL-10 [17] and decreased HLA-DR expression [18]. The resultant immune suppression appears to be confined to the blood compartment, however, while a hyperinflammatory state persists in tissues, which makes defining the role of cytokines in sepsis more difficult [19].
The inflammatory cytokine response to sepsis differs in neonates and adults. Although premature infants were once believed to have deficient production of proinflammatory cytokines, intrauterine fetal cord blood samples taken between 21 and 32 weeks gestation have demonstrated significant synthesis of IL-6, IL-8 and TNF $\alpha$ [20]. Term and preterm infants have been shown to have a higher percentage of IL-6positive and IL-8-positive cells than adults, with preterm infants having the highest percentage of IL-8-positive cells [21]. After stimulation with LPS, this increased percentage of proinflammatory cells in neonates is more pronounced and occurs faster than in adults. In addition, the compensatory anti-inflammatory response system in neonates appears to be immature, with both term and preterm infants demonstrating profoundly decreased IL-10 production and a lower amount of transforming growth factor beta-positive lymphocytes than do adults after LPS stimulation [14]. Although there is a decrease in the absolute amount of IL-10 produced, an increase in the IL-10:TNF $\alpha$ ratio has been reported in premature infants after LPS exposure; an increased IL-10:TNF $\alpha$ ratio in critically ill adults has been shown to be a negative predictor of outcome [22]. These perinatal and developmental influences on innate immunity and the inflammatory response may significantly alter the neonate's response to pathogen exposure.

\section{Neutrophils}

In addition to cytokine differences in the neonate, eosinophils, macrophages and polymorphonuclear neutrophils have reduced surface binding components and have defective opsonization, phagocytosis and antigen-processing capabilities, leading to a generally less robust response to pathogen exposure. Polymorphonuclear neutrophil function is the primary line of defense in the cellular immune system, and there is an alteration in both neutrophil function and survival in neonates versus adults. Neonates, especially those born prematurely, display a pattern of infectious diseases similar to the pattern seen in older individuals with severe neutropenia [20], have a markedly decreased neutrophil storage pool and cell mass $[23,24]$, and are more likely to develop neutropenia during systemic infection [25]. Functional deficiencies of neutrophils in preterm and stressed/septic neonates include chemotaxis [26], endothelial adherence [20], migration [27], phagocytosis and bactericidal potency $[20,28,29]$. The NADPH oxidase system, however, may be a first-line mechanism of innate immunity as there is a direct negative correlation between oxidative burst product generation and gestational age [20]. This could, however, have a detrimental effect on preterm infants as exaggerated oxygen free radical formation may contribute to the development of such neonatal diseases as retinopathy of prematurity and bronchopulmonary dysplasia, as well as to cardiovascular disease.

\section{Cardiovascular dysfunction in sepsis}

Sepsis is clinically characterized by systemic inflammation, cardiovascular dysfunction, an inability of oxygen delivery to 
meet oxygen demand, an altered substrate metabolism and, ultimately, multiorgan failure and death [30]. The mortality rate from sepsis doubles in patients who develop cardiovascular dysfunction and septic shock [1]. Little is known about the cardiovascular effects of sepsis in the neonate, but the developing cardiomyocyte differs from that of the adult and may lead to differences in the cardiac response to sepsis and inflammation. In addition to underlying differences in the structure of the neonatal cardiomyocyte, functional alterations in proliferative activity [31] and excitation-contraction coupling [32] have been identified. These differences may be mediated by alterations in calcium channel expression and activity [33,34], in ATP-sensitive potassium channel function [35] and in $\beta$-receptor coupling [36], and may contribute to differences in sepsis outcomes and therapeutic responses in neonates versus adults.

Cardiac dysfunction and cardiovascular collapse during sepsis result from increased levels of TNF $\alpha$ [37] and from increased cardiac myocyte production of nitric oxide and peroxynitrite [38], which leads to further DNA damage and ATP depletion [39], resulting in secondary energy failure [40]. In addition, serum from patients with septic shock directly causes a decreased maximum extent and peak velocity of contraction, activates transcription factors for proinflammatory cytokines and induces apoptosis in cultured myocytes [41]. LPSinduced production of TNF $\alpha$ has been associated with increased apoptosis and cell death in adult cultured cardiomyocytes [42], and this ventricular myocyte apoptosis has been linked to cardiovascular dysfunction in adult whole animal experiments [43]. Neonatal cardiomyocytes, however, do not exhibit an increase in apoptosis despite an increase in TNF $\alpha$ production after LPS exposure, suggesting another mechanism for sepsis-associated cardiovascular dysfunction in neonates [44].

Septic shock is characterized in adults by a hyperdynamic phase with decreased left ventricular ejection fraction, decreased systemic vascular resistance and an increased cardiac index $[45,46]$. Underlying coronary artery disease, cardiomyopathy and congestive heart failure may contribute to the systolic and diastolic ventricular dysfunction described in the setting of adult sepsis. The resultant myocardial depression does not appear to be related to ischemia, however, as the coronary blood flow and coronary sinus lactate levels have been found to be normal in patients with septic shock $[47,48]$.

Myocardial dysfunction in childhood septic shock reaches its maximum within hours and is the main cause of mortality $[30,49]$. In comparison with adults, children more often present in a nonhyperdynamic state with decreased cardiac output and increased systemic vascular resistance $[46,50]$ and can develop this nonhyperdynamic septic shock even after fluid resuscitation [51]. This low cardiac output is associated with an increase in mortality $[52,53]$. Owing to a limited number of research studies in the very young, the hemodynamic response of premature infants and neonates is not well understood, and the presenting hemodynamic abnormalities are more variable than in older children and adults [50]. Complicating the clinical evaluation of these patients is the observation that blood pressure is a poor indicator of systemic blood flow in neonates $[6,54]$.

In both premature and full-term infants, left ventricular systolic performance is highly dependent on afterload, which may increase the susceptibility of neonates to sudden cardiac deterioration in the setting of shock and vasoconstriction $[55,56]$. Newborn infants also have a relatively decreased left ventricular muscle mass [57] and an increased ratio of type I collagen (determinant of tissue rigidity) to type III collagen (provides elasticity) in myocardial tissue [58], which may account for the impaired left ventricular diastolic function and the alterations in mid-wall left ventricular fractional shortening seen in premature infants [59]. These physiologic abnormalities, coupled with the finding that the neonatal left ventricular myocardium already functions at a higher baseline contractile state [55], may limit the neonate's ability to increase the stroke volume or myocardial contractility in the setting of sepsis. Complicating the cardiovascular response to sepsis in the neonate are additional morbidities, including reopening of a patent ductus arteriosus and the development of persistent pulmonary hypertension of the newborn due to cytokine elaboration, acidosis and hypoxia in the setting of sepsis [52]. These underlying differences in anatomy, physiology and adaptive cardiovascular function exemplify the need to more specifically identify and understand the cardiovascular response to sepsis in the neonate in order to develop successful therapeutic strategies.

\section{Treatment}

The short-term goal of treatment is to optimize the perfusion and delivery of oxygen and nutrients, to correct and/or prevent metabolic derangements resulting from cellular hypoperfusion and to support organ and body functions until homeostasis is achieved $[30,60]$. Although our understanding of the pathophysiologic mechanisms of sepsis and septic shock has improved over the past 10 years, the mortality and morbidity associated with sepsis continues to be high $[2,30,46]$. Proinflammatory cytokines have been implicated in the pathogenesis of organ dysfunction during sepsis, but the modulation of single gene products (TNF $\alpha, \mathrm{IL}-1 \beta$, inducible nitric oxide synthase) and nonpeptide mediators (plateletactivating factor, prostaglandin or leukotriene inhibitors) has not been shown to improve mortality in sepsis and septic shock [41].

Unlike adult and pediatric critical medicine, where there are extensively studied multiple organ dysfunction scores and well-defined algorhythmic guidelines for treatment [61], there is a large amount of practice variability in neonatal sepsis. The American College of Critical Care Medicine concluded that 
the adult guidelines for hemodynamic support of septic shock are not applicable to children and neonates, and published guidelines for these younger age groups [52]. Premature neonates, however, were not specifically addressed.

\section{Antibiotics}

Empiric therapy aimed at the most probable causative pathogens should be started immediately upon suspicion of clinical sepsis, as a delay in the initiation of antibiotics has been associated with an increased risk of mortality in both pediatric $[30,62]$ and adult $[13,63,64]$ patients with sepsis. In neonates, special developmental characteristics such as immaturity of the hepatic and renal clearance systems need to be considered when prescribing an antibiotic regimen.

\section{Fluid resuscitation}

Fluid resuscitation is an important mainstay in the resuscitation of patients with septic shock, as marked hypovolemia may result from vasodilation and increased capillary leak. A significant reduction in mortality has been demonstrated when hemodynamic function is optimized within the first few hours after presentation of sepsis [60]. There has been longstanding debate about the use of colloids or crystalloids, but there is currently no strong evidence supporting the superiority of either fluid agent in the resuscitation of septic shock [13,65-68]. The underlying importance is the maintenance of preload and tissue perfusion. Fluid resuscitation is necessary in premature infants, but must be provided with caution due to the risks of developing intraventricular hemorrhage from fluctuations in cerebral perfusion and developing heart failure and/or pulmonary overcirculation from resultant left to right flow through a patent ductus arteriosus [52].

\section{Cardiovascular agents}

Adult sepsis is most often characterized by a hyperdynamic state with vasodilation, while neonatal sepsis may be a hypodynamic state with vasoconstriction and may respond better to inotrope and vasodilator therapy [30]. In both the recent recommendations of the American College of Critical Care [69] and an extensive evidence-based review of vasopressor support in septic shock [70], dopamine and norepinephrine are considered first-line agents in adult septic shock. An attenuated response to adrenergic stimulation has been reported in patients with septic shock, which is thought to result from the downregulation of receptors, uncoupling of receptors from adenylate cyclase or decreased production of cAMP [46]. This impaired effectiveness of exogenous adrenergic stimulation may be augmented in neonates due to a functionally immature autonomic nervous system $[30,71]$ and elevated baseline levels of catecholamines [72-75], especially in premature infants.

Randomized controlled trials of vasopressors in neonates are extremely rare. In a recent study investigating dopamine versus epinephrine for cardiovascular support in low birth- weight infants, both agents were found to be efficacious in improving the mean arterial blood pressure - but epinephrine was associated with more short-term adverse effects such as enhanced chronotropic response, hyperglycemia requiring insulin treatment and increased plasma lactate levels [76]. There is only a weak correlation between blood pressure and systemic blood flow in neonates [6], and, although a recent metanalysis found dopamine to be superior to dobutamine in improving blood pressure, a randomized controlled trial showed that dobutamine increased systemic blood flow more effectively than dopamine [77]. According to recently published clinical practice parameters, however, dopamine remains the first-line agent in neonates, and epinephrine may be used in dopamine-resistant septic shock [52]. If low cardiac output and high systemic vascular resistance persist, dobutamine and/or a type III phosphodiesterase inhibitor may be indicated $[46,52]$. Phosphodiesterase inhibitors have the additional benefits of TNF $\alpha$ attenuation and decreased myocardial inducible nitric oxide synthase activity [46], and milrinone has been shown to improve cardiovascular function in pediatric patients with septic shock [78].

Milrinone is a selective phosphodiesterase type III inhibitor that has proven safe and efficacious in certain clinical scenarios in pediatric patients $[78,79]$. Many of these studies, however, have been conducted by providing a loading dose of milrinone followed by a continuous infusion. In practice, physicians often forego the loading dose, especially in patients that may have decreased preload to avoid any untoward hemodynamic effects including undue hypotension. The time to reach steady state is therefore prolonged compared with the pharmacokinetics previously described [80]. Despite this approach, many patients are concomitantly on catecholamine infusions, which have a very short half-life. The glomerular filtration rate in term neonates is $20 \mathrm{ml} / \mathrm{min} \times 1.73 \mathrm{~m}^{2}$, which is generally twice that of premature newborns [81]. The glomerular filtration rate improves over the first several weeks of life in all newborns but the velocity at which it improves is less in premature infants. In term newborns, the glomerular filtration rate doubles in the first 2 weeks of life [82,83]. These differences in glomerular filtration rate values among varying gestational age newborns impact the administration of medications that are primarily eliminated in the renal system. This impact is pertinent in milrinone use, and therefore dosing is often renally adjusted in neonates. In cases of persistent pulmonary hypertension of the newborn associated with sepsis, inhaled nitric oxide may help reduce pulmonary vascular resistance and off-load the right ventricle.

\section{Immunomodulating agents}

Agents such as corticosteroids, pentoxifylline and recombinant human-activated protein $\mathrm{C}$ have been studied as adjunctive treatments for sepsis in adults and neonates (Table 1). Recombinant human-activated protein $\mathrm{C}$ is the only adjunctive therapy approved for the treatment of severe sepsis in adults who have a high risk of death [84,85]. 
Table 1

\section{Immunomodulating agents in neonatal and adult sepsis}

\begin{tabular}{|c|c|c|}
\hline Agent & Neonates & Adults \\
\hline \multirow[t]{3}{*}{ Steroids } & \multirow[t]{3}{*}{$\begin{array}{l}\text { No evidence of improved outcome in critically } \\
\text { ill infants or children with sepsis [89] }\end{array}$} & $\begin{array}{l}\text { High-dose: no benefit [101] or reduction in mortality [102], } \\
\text { may actually increase mortality [86] }\end{array}$ \\
\hline & & Hemodynamically stable: no benefit [101] \\
\hline & & Low-dose, long-course: may decrease mortality [87] \\
\hline
\end{tabular}

\begin{tabular}{|c|c|}
\hline \multirow[t]{3}{*}{$\begin{array}{l}\text { Intravenous } \\
\text { immunoglobulin }\end{array}$} & $\begin{array}{l}\text { Prevention: } 3 \% \text { reduction in sepsis, } 4 \% \text { reduction } \\
\text { in any serious infection; no change in mortality, } \\
\text { necrotizing enterocolitis, bronchopulmonary dyspla } \\
\text { intraventricular hemorrhage or length of stay [103] }\end{array}$ \\
\hline & $\begin{array}{l}\text { Suspected infection: decrease in mortality of } \\
\text { borderline statistical significance [104] }\end{array}$ \\
\hline & Proven infection: no change in mortality [104] \\
\hline \multirow[t]{2}{*}{$\begin{array}{l}\text { Colony-stimulating } \\
\text { factors }\end{array}$} & $\begin{array}{l}\text { Treatment: rhG-CSF and rhGM-CSF not effective } \\
\text { in reducing mortality }[106,107]\end{array}$ \\
\hline & $\begin{array}{l}\text { Prophylaxis: both agents effective in correcting } \\
\text { neutropenia in premature neonates [106 107]; } \\
\text { rhGM-CSF may decrease infection in infants } \\
<32 \text { weeks who are neutropenic or at risk for } \\
\text { developing neutropenia [106,107]; rhGM-CSF } \\
\text { decreases mortality in neutropenic neonates with } \\
\text { sepsis [107] }\end{array}$ \\
\hline
\end{tabular}

Polyclonal: significant reduction in mortality [105]

rhG-CSF febrile neutropenia: shorter hospital stay, no difference in mortality [111]

Monoclonal: HA-1A, E5, IL-1, phospholipase $\mathrm{A}_{2}$, adhesion molecules and contact factors all show no benefit [86]

rhG-CSF in pneumonia with severe sepsis: no difference in mortality, ARDS or adverse events [108,109]; no difference in days of ventilatory support or intensive care unit stay [108] rhG-CSF in severe sepsis: small study shows a significant decrease in mortality [110]

rhGM-CSF in severe sepsis: no change in mortality [112,113]; improved $\mathrm{PaO} 2 / \mathrm{FiO}_{2}$ ratio [112] and clearance of infection [113]

Activated protein C No randomized trials in neonates $[114,115]$

Severe sepsis and increased risk of death: improved organ function and decreased mortality [114]; 19.4\% reduction in relative risk of death [84]; cost-effective [117]

Two case reports with survival without adverse Severe sepsis and low risk of death: no benefit [118] events $[114,116]$

Large pediatric clinical trial stopped early due to no improvement in mortality and increased intracranial hemorrhage [98]

Pentoxifylline Decreased mortality, circulatory compromise,
disseminated intravascular coagulopathy and necrotizing enterocolitis versus placebo [94]

Reduces mortality without adverse effects [119] No change in 28-day mortality [95] Improved cardiopulmonary function [96] and hemodynamic performance [95]

No adverse effects $[95,96]$

ARDS, acute respiratory distress syndrome; rhG-CSF, recombinant human granulocyte colony-stimulating factor; rhGM-CSF, recombinant human granulocyte-macrophage colony-stimulating factor.

\section{Corticosteroids}

The use of corticosteroids in the management of sepsis has evolved with the identification of relative adrenal insufficiency, which occurs in 50-75\% of patients with septic shock [13]. While adult studies of high-dose corticosteroids have not shown a benefit or reduction in mortality [86], lower doses of steroids given over a longer course may actually decrease mortality in adult patients with sepsis [87]. The use of corticosteroids in the treatment of sepsis in neonates and children remains relatively untested. A recent study has shown that $44 \%$ of children with septic shock are adrenally insufficient [88], but a large cohort study of steroid administration to children and infants with severe sepsis showed no improvement in outcome and an increase in mortality in a subset of patients [89]. In neonates, both hydrocortisone and low-dose dexamethasone have been 
shown to effectively increase blood pressure in refractory hypotension [90,91], but steroids should be used with caution as early administration of high-dose corticosteroids has the additional risk of impaired neurodevelopment and clinically significant disability later in life [92].

\section{Pentoxifylline}

Pentoxifylline is a methylxanthine derivative and nonspecific phosphodiesterase inhibitor that has been shown to be beneficial in the treatment of a variety of illnesses in all age groups, but only a handful of studies have focused on the use of pentoxifylline in the treatment of sepsis in adults and neonates [93]. In premature neonates with sepsis, pentoxifylline has been shown to decrease IL- 6 and TNF $\alpha$ levels, to decrease the clinical symptoms of necrotizing enterocolitis, to reduce the development of cardiac, renal or hepatic failure, to decrease the incidence of disseminated intravascular coagulopathy and to improve blood pressure and survival rates [94]. Adult studies have shown improved cardiopulmonary and hemodynamic function in severe sepsis $[95,96]$ but did not show a reduction in 28-day mortality [96]. Both neonatal and adult studies showed no adverse effects of the medication.

\section{Recombinant human-activated protein C}

At least $80 \%$ of children and adults develop an acquired deficiency of protein C during severe sepsis, and this deficiency is associated with adverse outcomes, such as multiple organ failure and mortality [97]. In the PROWESS trial, the use of in the treatment of adults with severe sepsis and a high risk of death showed a relative risk reduction of mortality of 19\% [84]. A large clinical trial in pediatric patients with sepsis was stopped early due to a lack of demonstrated benefit and the finding of an increased risk of intracranial hemorrhage, especially in infants younger than 60 days of life [98]. In addition to the potential risk for increased bleeding in the neonatal population, the efficacy of recombinant humanactivated protein $\mathrm{C}$ may also be different in neonates due to underlying developmental differences in the coagulation pathway. The anticoagulant effect of recombinant humanactivated protein $\mathrm{C}$ has been shown to be decreased in neonatal cord plasma, which is due, in part, to the lower levels of tissue factor pathway inhibitor, antithrombin and protein $\mathrm{S}$ in neonatal versus adult plasma $[84,85]$.

\section{Conclusion}

The incidence of neonatal sepsis is significant, with suspected sepsis being the most common diagnosis on admission to the neonatal intensive care unit in the United States [99]. Research regarding neonatal sepsis, and the cardiovascular effects of sepsis in particular, is relatively lacking. The cost of neonatal sepsis is high, with very low birthweight infants and low birthweight infants with sepsis consuming twice as much financial resource than do infants with respiratory distress syndrome [3]. Future medical and social resource utilization is also increased, as there is a significant increase in the morbidity of infants surviving severe infection, with a $30-400 \%$ odds increase of later neurodevelopmental impairment [100].

In the neonate, there are multiple developmental alterations in both the response to pathogens and the response to treatment that distinguish this age group from adults. Differences in innate immunity and cytokine response may predispose neonates to the harmful effects of proinflammatory cytokines and oxidative stress, leading to severe organ dysfunction and sequelae during infection and inflammation [14]. Underlying differences in cardiovascular anatomy, function and response to treatment may further alter the neonate's response to pathogen exposure. We must therefore gain a greater understanding of these developmental changes in order to adequately understand and treat immune and inflammatoryrelated cardiovascular compromise in the neonatal population. This remarkably unstudied area of neonatal sepsis is paramount, as cardiac failure remains a main cause of death in this disease state. Translational research will be the cornerstone of this research initiative, as therapeutic agents will need to be developmentally targeted in order to be effective.

\section{Competing interests}

The authors declare that they have no competing interests.

\section{Authors' contributions}

WAL was primarily responsible for the conception and design of the present review, as well as the intellectual content, drafting and revision of the manuscript. TMH and JAB also contributed significantly to the design of the review, added important intellectual content and participated in the drafting and revision of the manuscript. All three authors gave final approval of the version to be published.

\section{Acknowledgement}

WAL's research was supported by NIH/NICHD HD043003-04.

\section{References}

1. Vincent JL, Sakr Y, Sprung CL, Ranieri VM, Reinhart K, Gerlach H, Moreno R, Carlet J, Le Gall JR, Payen D: Sepsis in European intensive care units: results of the SOAP study. Crit Care Med 2006, 34:344-353.

2. Angus DC, Linde-Zwirble WT, Lidicker J, Clermont G, Carcillo J, Pinsky MR: Epidemiology of severe sepsis in the United States: analysis of incidence, outcome, and associated costs of care. Crit Care Med 2001, 29:1303-1310.

3. Watson RS, Carcillo JA, Linde-Zwirble WT, Clermont G, Lidicker $J$, Angus DC: The epidemiology of severe sepsis in children in the United States. Am J Respir Crit Care Med 2003, 167:695701.

4. Meadow W, Frain L, Ren Y, Lee G, Soneji S, Lantos J: Serial assessment of mortality in the neonatal intensive care unit by algorithm and intuition: certainty, uncertainty, and informed consent. Pediatrics 2002, 109:878-886.

5. Stoll BJ, Hansen N, Fanaroff AA, Wright LL, Carlo WA, Ehrenkranz RA, Lemons JA, Donovan EF, Stark AR, Tyson JE, et al.: Late-onset sepsis in very low birth weight neonates: the experience of the NICHD Neonatal Research Network. Pediatrics 2002, 110:285-291.

6. Evans N: Which inotrope for which baby? Arch Dis Child Fetal Neonatal Ed 2006, 91:F213-F220. 
7. Fagoaga OR, Nehlsen-Cannarella SL: Maternal modulation of neonatal immune system development. Dev Immunol 2002, 9: 9-17.

8. Aaltonen R, Heikkinen T, Hakala K, Laine K, Alanen A: Transfer of proinflammatory cytokines across term placenta. Obstet Gynecol 2005, 106:802-807.

9. Mohan AR, Loudon JA, Bennett PR: Molecular and biochemical mechanisms of preterm labour. Semin Fetal Neonatal Med 2004, 9:437-444.

10. Molloy EJ, O'Neill AJ, Grantham JJ, Sheridan-Pereira M, Fitzpatrick JM, Webb DW, Watson RW: Labor promotes neonatal neutrophil survival and lipopolysaccharide responsiveness. Pediatr Res 2004, 56:99-103.

11. Gessler P, Dahinden C: Increased respiratory burst and increased expression of complement receptor-3 (CD11b/ CD18) and of IL-8 receptor-A in neutrophil granulocytes from newborns after vaginal delivery. Biol Neonate 2003, 83:107-112.

12. Bozza FA, Salluh JI, Japiassu AM, Soares M, Assis EF, Gomes RN, Bozza MT, Castro-Faria-Neto HC, Bozza PT: Cytokine profiles as markers of disease severity in sepsis: a multiplex analysis. Crit Care 2007, 11:R49.

13. Rangel-Frausto MS: Sepsis: still going strong. Arch Med Res 2005, 36:672-681.

14. Schultz C, Temming P, Bucsky P, Gopel W, Strunk T, Hartel C: Immature anti-inflammatory response in neonates. Clin Exp Immuno/ 2004, 135:130-136.

15. Kox WJ, Volk T, Kox SN, Volk HD: Immunomodulatory therapies in sepsis. Intensive Care Med 2000, 26(Suppl 1):S124-S128.

16. Bone RC: Sir Isaac Newton, sepsis, SIRS, and CARS. Crit Care Med 1996, 24:1125-1128.

17. Platzer $C$, Meisel C, Vogt K, Platzer M, Volk HD: Up-regulation of monocytic IL-10 by tumor necrosis factor-alpha and CAMP elevating drugs. Int Immunol 1995, 7:517-523.

18. Kox WJ, Bone RC, Krausch D, Docke WD, Kox SN, Wauer H, Egerer K, Querner S, Asadullah K, von Baehr R, et al.: Interferon gamma-1b in the treatment of compensatory anti-inflammatory response syndrome. A new approach: proof of principle. Arch Intern Med 1997, 157:389-393.

19. Takala A, Nupponen I, Kylanpaa-Back ML, Repo H: Markers of inflammation in sepsis. Ann Med 2002, 34:614-623.

20. Strunk T, Temming P, Gembruch U, Reiss I, Bucsky P, Schultz C: Differential maturation of the innate immune response in human fetuses. Pediatr Res 2004, 56:219-226.

21. Schultz C, Rott C, Temming P, Schlenke P, Moller JC, Bucsky P: Enhanced interleukin-6 and interleukin-8 synthesis in term and preterm infants. Pediatr Res 2002, 51:317-322.

22. Dembinski J, Behrendt D, Martini R, Heep A, Bartmann P: Modulation of pro- and anti-inflammatory cytokine production in very preterm infants. Cytokine 2003, 21:200-206.

23. Ohls RK, Li Y, Abdel-Mageed A, Buchanan G, Jr, Mandell L, Christensen RD: Neutrophil pool sizes and granulocyte colonystimulating factor production in human mid-trimester fetuses. Pediatr Res 1995, 37:806-811.

24. Carr R, Huizinga TW: Low soluble FcRIII receptor demonstrates reduced neutrophil reserves in preterm neonates [letter]. Arch Dis Child Fetal Neonatal Ed 2000, 83:F160.

25. Molloy EJ, O'Neill AJ, Grantham JJ, Sheridan-Pereira M, Fitzpatrick JM, Webb DW, Watson RW: Granulocyte colony-stimulating factor and granulocyte-macrophage colony-stimulating factor have differential effects on neonatal and adult neutrophil survival and function. Pediatr Res 2005, 57:806-812.

26. Weinberger B, Laskin DL, Mariano TM, Sunil VR, DeCoste CJ, Heck DE, Gardner CR, Laskin JD: Mechanisms underlying reduced responsiveness of neonatal neutrophils to distinct chemoattractants. J Leukoc Biol 2001, 70:969-976.

27. Nybo M, Sorensen O, Leslie R, Wang P: Reduced expression of C5a receptors on neutrophils from cord blood. Arch Dis Child Fetal Neonatal Ed 1998, 78:F129-F132.

28. Carr R: Neutrophil production and function in newborn infants. Br J Haematol 2000, 110:18-28.

29. Nupponen I, Turunen R, Nevalainen T, Peuravuori H, Pohjavuori M, Repo H, Andersson S: Extracellular release of bactericidal/ permeability-increasing protein in newborn infants. Pediatr Res 2002, 51:670-674.

30. von Rosenstiel N, von Rosenstiel I, Adam D: Management of sepsis and septic shock in infants and children. Paediatr Drugs 2001, 3:9-27.
31. Huttenbach Y, Ostrowski ML, Thaller D, Kim HS: Cell proliferation in the growing human heart: MIB-1 immunostaining in preterm and term infants at autopsy. Cardiovasc Pathol 2001 10:119-123

32. Escobar AL, Ribeiro-Costa R, Villalba-Galea C, Zoghbi ME, Perez CG, Mejia-Alvarez R: Developmental changes of intracellular $\mathrm{Ca}^{2+}$ transients in beating rat hearts. Am J Physiol Heart Circ Physiol 2004, 286:H971-H978.

33. Wetzel GT, Chen F, Klitzner TS: L- and T-type calcium channels in acutely isolated neonatal and adult cardiac myocytes. Pediatr Res 1991, 30:89-94.

34. Huang J, Xu L, Thomas M, Whitaker K, Hove-Madsen L, Tibbits GF: L-type $\mathrm{Ca}^{2+}$ channel function and expression in neonatal rabbit ventricular myocytes. Am J Physiol Heart Circ Physiol 2006, 290: $\mathrm{H} 2267-\mathrm{H} 2276$.

35. Morrissey A, Parachuru L, Leung M, Lopez G, Nakamura TY, Tong $X$, Yoshida $\mathrm{H}$, Srivastiva S, Chowdhury PD, Artman M, et al.: Expression of ATP-sensitive $\mathrm{K}^{+}$channel subunits during perinatal maturation in the mouse heart. Pediatr Res 2005, 58: 185-192.

36. Kuznetsov V, Pak E, Robinson RB, Steinberg SF: Beta 2-adrenergic receptor actions in neonatal and adult rat ventricular myocytes. Circ Res 1995, 76:40-52.

37. Kumar A, Kumar A, Paladugu B, Mensing J, Parrillo JE: Transforming growth factor-beta1 blocks in vitro cardiac myocyte depression induced by tumor necrosis factor-alpha, interleukin-1beta, and human septic shock serum. Crit Care Med 2007, 35:358-364.

38. Khadour FH, Panas D, Ferdinandy P, Schulze C, Csont T, Lalu MM, Wildhirt SM, Schulz R: Enhanced NO and superoxide generation in dysfunctional hearts from endotoxemic rats. Am J Physiol Heart Circ Physiol 2002, 283:H1108-H1115.

39. Watts JA, Kline JA, Thornton LR, Grattan RM, Brar SS: Metabolic dysfunction and depletion of mitochondria in hearts of septic rats. J Mol Cell Cardio/ 2004, 36:141-150.

40. Carcillo JA: Pediatric septic shock and multiple organ failure. Crit Care Clin 2003, 19:413-440, viii.

41. Kumar A, Kumar A, Michael P, Brabant D, Parissenti AM, Ramana $\mathrm{CV}, \mathrm{Xu} \mathrm{X}$, Parrillo JE: Human serum from patients with septic shock activates transcription factors STAT1, IRF1, and NFkappaB and induces apoptosis in human cardiac myocytes. J Biol Chem 2005, 280:42619-42626.

42. Comstock KL, Krown KA, Page MT, Martin D, Ho P, Pedraza M, Castro EN, Nakajima N, Glembotski CC, Quintana PJ, et al:: LPS-induced TNF-alpha release from and apoptosis in rat cardiomyocytes: obligatory role for CD14 in mediating the LPS response. J Mol Cell Cardiol 1998, 30:2761-2775.

43. Lancel S, Petillot P, Favory R, Stebach N, Lahorte C, Danze PM, Vallet B, Marchetti P, Neviere R: Expression of apoptosis regulatory factors during myocardial dysfunction in endotoxemic rats. Crit Care Med 2005, 33:492-496.

44. Hickson-Bick DL, Jones C, Buja LM: The response of neonatal rat ventricular myocytes to lipopolysaccharide-induced stress. Shock 2006, 25:546-552.

45. Maeder M, Fehr T, Rickli H, Ammann P: Sepsis-associated myocardial dysfunction: diagnostic and prognostic impact of cardiac troponins and natriuretic peptides. Chest 2006, 129: 1349-1366.

46. Tabbutt S: Heart failure in pediatric septic shock: utilizing inotropic support. Crit Care Med 2001, 29:S231-S236.

47. Belcher E, Mitchell J, Evans T: Myocardial dysfunction in sepsis: no role for NO? Heart 2002, 87:507-509.

48. Krishnagopalan S, Kumar A, Parrillo JE, Kumar A: Myocardial dysfunction in the patient with sepsis. Curr Opin Crit Care 2002, 8:376-388

49. Mercier JC, Beaufils F, Hartmann JF, Azema D: Hemodynamic patterns of meningococcal shock in children. Crit Care Med 1988, 16:27-33

50. McKiernan CA, Lieberman SA: Circulatory shock in children: an overview. Pediatr Rev 2005, 26:451-460.

51. Ceneviva G, Paschall JA, Maffei F, Carcillo JA: Hemodynamic support in fluid-refractory pediatric septic shock. Pediatrics 1998, 102:e19 [doi:10.1542/peds.102.2.e19].

52. Carcillo JA, Fields Al: Clinical practice parameters for hemodynamic support of pediatric and neonatal patients in septic shock. Crit Care Med 2002, 30:1365-1378.

53. Pollack MM, Fields Al, Ruttimann UE: Distributions of cardiopul- 
monary variables in pediatric survivors and nonsurvivors of septic shock. Crit Care Med 1985, 13:454-459.

54. Kluckow M, Evans N: Relationship between blood pressure and cardiac output in preterm infants requiring mechanical ventilation. J Pediatr 1996, 129:506-512.

55. Crepaz R, Pitscheider W, Radetti G, Gentili L: Age-related variation in left ventricular myocardial contractile state expressed by the stress velocity relation. Pediatr Cardiol 1998, 19:463-467.

56. Toyono M, Harada K, Takahashi Y, Takada G: Maturational changes in left ventricular contractile state. Int J Cardiol 1998, 64:247-252

57. Joyce JJ, Dickson PI, Qi N, Noble JE, Raj JU, Baylen BG: Normal right and left ventricular mass development during early infancy. Am J Cardiol 2004, 93:797-801.

58. Marijianowski MM, van der Loos CM, Mohrschladt MF, Becker AE: The neonatal heart has a relatively high content of total collagen and type I collagen, a condition that may explain the less compliant state. J Am Coll Cardiol 1994, 23:1204-1208.

59. Kozak-Barany A, Jokinen E, Saraste M, Tuominen J, Valimaki I: Development of left ventricular systolic and diastolic function in preterm infants during the first month of life: a prospective follow-up study. J Pediatr 2001, 139:539-545.

60. Rivers E, Nguyen B, Havstad S, Ressler J, Muzzin A, Knoblich B, Peterson E, Tomlanovich M: Early goal-directed therapy in the treatment of severe sepsis and septic shock. N Engl J Med 2001, 345:1368-1377.

61. Tarnow-Mordi WO: What is the role of neonatal organ dysfunction and illness severity scores in therapeutic studies in sepsis? Pediatr Crit Care Med 2005, 6:S135-S137.

62. Cartwright K, Reilly S, White D, Stuart J: Early treatment with parenteral penicillin in meningococcal disease. BMJ 1992, 305:143-147.

63. Houck PM, Bratzler DW, Nsa W, Ma A, Bartlett JG: Timing of antibiotic administration and outcomes for Medicare patients hospitalized with community-acquired pneumonia. Arch Intern Med 2004, 164:637-644.

64. Iregui M, Ward S, Sherman G, Fraser VJ, Kollef MH: Clinical importance of delays in the initiation of appropriate antibiotic treatment for ventilator-associated pneumonia. Chest 2002, 122:262-268

65. So KW, Fok TF, Ng PC, Wong WW, Cheung KL: Randomised controlled trial of colloid or crystalloid in hypotensive preterm infants. Arch Dis Child Fetal Neonatal Ed 1997, 76:F43-F46.

66. Upadhyay M, Singhi S, Murlidharan J, Kaur N, Majumdar S: Randomized evaluation of fluid resuscitation with crystalloid (saline) and colloid (polymer from degraded gelatin in saline) in pediatric septic shock. Indian Pediatr 2005, 42:223-231.

67. Su F, Wang Z, Cai Y, Rogiers P, Vincent JL: Fluid resuscitation in severe sepsis and septic shock: albumin, hydroxyethyl starch, gelatin or ringer's lactate - does it really make a difference? Shock 2007, 27:520-526.

68. Finfer S, Bellomo R, Boyce N, French J, Myburgh J, Norton R: A comparison of albumin and saline for fluid resuscitation in the intensive care unit. N Engl J Med 2004, 350:2247-2256.

69. Hollenberg SM, Ahrens TS, Annane D, Astiz ME, Chalfin DB, Dasta JF, Heard SO, Martin C, Napolitano LM, Susla GM, et al.: Practice parameters for hemodynamic support of sepsis in adult patients: 2004 update. Crit Care Med 2004, 32:19281948.

70. Beale RJ, Hollenberg SM, Vincent JL, Parrillo JE: Vasopressor and inotropic support in septic shock: an evidence-based review. Crit Care Med 2004, 32:S455-S465.

71. Longin E, Gerstner T, Schaible T, Lenz T, Konig S: Maturation of the autonomic nervous system: differences in heart rate variability in premature vs. term infants. J Perinat Med 2006, 34: 303-308.

72. Hirsimaki H, Kero P, Ekblad H, Scheinin M, Saraste M, Erkkola R: Mode of delivery, plasma catecholamines and Dopplerderived cardiac output in healthy term newborn infants. Biol Neonate 1992, 61:285-293.

73. Kallio J, Karlsson R, Toppari J, Helminen T, Scheinin M, Kero P: Antenatal dexamethasone treatment decreases plasma catecholamine levels in preterm infants. Pediatr Res 1998, 43:801807.

74. Newnham JP, Marshall CL, Padbury JF, Lam RW, Hobel CJ, Fisher $\mathrm{DA}$ : Fetal catecholamine release with preterm delivery. $\mathrm{Am} J$ Obstet Gynecol 1984, 149:888-893.
75. Teitel DF, Sidi D, Chin T, Brett C, Heymann MA, Rudolph AM: Developmental changes in myocardial contractile reserve in the lamb. Pediatr Res 1985, 19:948-955.

76. Valverde E, Pellicer A, Madero R, Elorza D, Quero J, Cabanas F: Dopamine versus epinephrine for cardiovascular support in low birth weight infants: analysis of systemic effects and neonatal clinical outcomes. Pediatrics 2006, 117:e1213e1222.

77. Osborn D, Evans N, Kluckow M: Randomized trial of dobutamine versus dopamine in preterm infants with low systemic blood flow. J Pediatr 2002, 140:183-191.

78. Barton P, Garcia J, Kouatli A, Kitchen L, Zorka A, Lindsay C, Lawless S, Giroir B: Hemodynamic effects of i.v. milrinone lactate in pediatric patients with septic shock. A prospective, double-blinded, randomized, placebo-controlled, interventional study. Chest 1996, 109:1302-1312.

79. Hoffman TM, Wernovsky G, Atz AM, Kulik TJ, Nelson DP, Chang AC, Bailey JM, Akbary A, Kocsis JF, Kaczmarek R, et al.: Efficacy and safety of milrinone in preventing low cardiac output syndrome in infants and children after corrective surgery for congenital heart disease. Circulation 2003, 107:996-1002.

80. Bailey JM, Hoffman TM, Wessel DL, Nelson DP, Atz AM, Chang AC, Kulik TJ, Spray TL, Akbary A, Miller RP, et al.: A population pharmacokinetic analysis of milrinone in pediatric patients after cardiac surgery. J Pharmacokinet Pharmacodyn 2004, 31: 43-59.

81. Guignard JP, Torrado A, Da Cunha O, Gautier E: Glomerular filtration rate in the first three weeks of life. J Pediatr 1975, 87: 268-272.

82. Bueva A, Guignard JP: Renal function in preterm neonates. Pediatr Res 1994, 36:572-577.

83. Vanpee M, Blennow M, Linne T, Herin P, Aperia A: Renal function in very low birth weight infants: normal maturity reached during early childhood. J Pediatr 1992, 121:784-788.

84. Bernard GR, Vincent JL, Laterre PF, LaRosa SP, Dhainaut JF, Lopez-Rodriguez A, Steingrub JS, Garber GE, Helterbrand JD, Ely $\mathrm{EW}$, et al.: Efficacy and safety of recombinant human activated protein $C$ for severe sepsis. N Engl J Med 2001, 344:699-709.

85. Cvirn G, Koestenberger M, Leschnik B, Male C, Kutschera J Ferstl U, Muntean W, Juergens G, Gallistl S: Protein S modulates the anticoagulant action of recombinant human activated protein C: a comparison between neonates and adults. Br J Pharmacol 2005, 146:1082-1086.

86. Zeni F, Freeman B, Natanson C: Anti-inflammatory therapies to treat sepsis and septic shock: a reassessment. Crit Care Med 1997, 25:1095-1100.

87. Annane D, Sebille V, Charpentier C, Bollaert PE, Francois B Korach JM, Capellier G, Cohen Y, Azoulay E, Troche G, et al:: Effect of treatment with low doses of hydrocortisone and fludrocortisone on mortality in patients with septic shock. JAMA 2002, 288:862-871

88. Pizarro CF, Troster EJ, Damiani D, Carcillo JA: Absolute and relative adrenal insufficiency in children with septic shock. Crit Care Med 2005, 33:855-859.

89. Markovitz BP, Goodman DM, Watson RS, Bertoch D, Zimmerman $\mathrm{J}$ : A retrospective cohort study of prognostic factors associated with outcome in pediatric severe sepsis: what is the role of steroids? Pediatr Crit Care Med 2005, 6:270-274.

90. Bourchier D, Weston PJ: Randomised trial of dopamine compared with hydrocortisone for the treatment of hypotensive very low birthweight infants. Arch Dis Child Fetal Neonatal Ed 1997, 76:F174-F178

91. Noori S, Siassi B, Durand M, Acherman R, Sardesai S, Ramanathan R: Cardiovascular effects of low-dose dexamethasone in very low birth weight neonates with refractory hypotension. Biol Neonate 2006, 89:82-87.

92. Yeh TF, Lin YJ, Lin HC, Huang CC, Hsieh WS, Lin CH, Tsai $\mathrm{CH}$ : Outcomes at school age after postnatal dexamethasone therapy for lung disease of prematurity. N Engl J Med 2004 350:1304-1313.

93. Bell SG: Immunomodulation, part I: pentoxifylline. Neonatal Netw 2005, 24:45-48

94. Lauterbach R, Pawlik D, Kowalczyk D, Ksycinski W, Helwich E, Zembala M: Effect of the immunomodulating agent, pentoxifylline, in the treatment of sepsis in prematurely delivered infants: a placebo-controlled, double-blind trial. Crit Care Med 1999, 27:807-814. 
95. Bacher A, Mayer N, Klimscha W, Oismuller C, Steltzer H, Hammerle A: Effects of pentoxifylline on hemodynamics and oxygenation in septic and nonseptic patients. Crit Care Med 1997, 25:795-800.

96. Staubach KH, Schroder J, Stuber F, Gehrke K, Traumann E, Zabel $P$ : Effect of pentoxifylline in severe sepsis: results of a randomized, double-blind, placebo-controlled study. Arch Surg 1998, 133:94-100.

97. Giroir BP: Recombinant human activated protein $\mathbf{C}$ for the treatment of severe sepsis: is there a role in pediatrics? Curr Opin Pediatr 2003, 15:92-96.

98. Nadel S, Goldstein B, Williams MD, Dalton H, Peters M, Macias WL, Abd-Allah SA, Levy H, Angle R, Wang D, et al.: Drotrecogin alfa (activated) in children with severe sepsis: a multicentre phase III randomised controlled trial. Lancet 2007, 369:836843.

99. Spitzer AR, Kirkby S, Kornhauser M: Practice variation in suspected neonatal sepsis: a costly problem in neonatal intensive care. J Perinatol 2005, 25:265-269.

100. Tarnow-Mordi WO: What is the role of neonatal organ dysfunction and illness severity scores in therapeutic studies in sepsis? Pediatr Crit Care Med 2005, 6(3 Suppl):S135-S137.

101. LaRosa SP: Use of corticosteroids in the sepsis syndrome: what do we know now? Cleve Clin J Med 2005, 72:1121-1127.

102. Annane D, Bellissant E, Bollaert PE, Briegel J, Keh D, Kupfer Y: Corticosteroids for severe sepsis and septic shock: a systematic review and meta-analysis. BMJ, doi:10.1136/bmj.38181. 482222.55 (published 2 August 2004)

103. Ohlsson A, Lacy JB: Intravenous immunoglobulin for preventing infection in preterm and/or low-birth-weight infants. Cochrane Database Syst Rev 2004, Issue 1. Art. No.: CD000361. DOI: 10.1002/14651858.CD000361.pub2.

104. Ohlsson A, Lacy JB: Intravenous immunoglobulin for suspected or subsequently proven infection in neonates. Cochrane Database Syst Rev 2004, Issue 1. Art. No.: CD001239. DOI: 10.1002/14651858.CD001239.pub2.

105. Alejandria MM, Lansang MA, Dans LF, Mantaring JB: Intravenous immunoglobulin for treating sepsis and septic shock. Cochrane Database Syst Rev 2002, Issue 1. Art. No.: CD001090. DOI: 10.1002/14651858.CD001090.

106. Bell SG: Immunomodulation, part II: granulocyte colony-stimulating factors. Neonatal Netw 2006, 25:65-70.

107. Carr R, Modi N, Dore C: G-CSF and GM-CSF for treating or preventing neonatal infections. Cochrane Database Syst Rev 2003, Issue 3. Art. No.: CD003066. DOI: 10.1002/14651858. CD003066.

108. Root RK, Lodato RF, Patrick W, Cade JF, Fotheringham N, Milwee S, Vincent JL, Torres A, Rello J, Nelson S: Multicenter, doubleblind, placebo-controlled study of the use of filgrastim in patients hospitalized with pneumonia and severe sepsis. Crit Care Med 2003, 31:367-373.

109. Wunderink R, Leeper K, Jr, Schein R, Nelson S, DeBoisblanc B, Fotheringham N, Logan E: Filgrastim in patients with pneumonia and severe sepsis or septic shock. Chest 2001, 119:523529.

110. Stephens DP, Fisher DA, Currie BJ: An audit of the use of granulocyte colony-stimulating factor in septic shock. Intern Med J 2002, 32:143-148.

111. Garcia-Carbonero R, Mayordomo Jl, Tornamira MV, Lopez-Brea M, Rueda A, Guillem V, Arcediano A, Yubero A, Ribera F, Gomez $C$, et al:: Granulocyte colony-stimulating factor in the treatment of high-risk febrile neutropenia: a multicenter randomized trial. J Nat/ Cancer Inst 2001, 93:31-38.

112. Presneill JJ, Harris T, Stewart AG, Cade JF, Wilson JW: A randomized phase II trial of granulocyte-macrophage colonystimulating factor therapy in severe sepsis with respiratory dysfunction. Am J Respir Crit Care Med 2002, 166:138-143.

113. Rosenbloom AJ, Linden PK, Dorrance A, Penkosky N, CohenMelamed MH, Pinsky MR: Effect of granulocyte-monocyte colony-stimulating factor therapy on leukocyte function and clearance of serious infection in nonneutropenic patients. Chest 2005, 127:2139-2150.

114. Frommhold D, Birle A, Linderkamp O, Zilow E, Poschl J: Drotrecogin alpha (activated) in neonatal septic shock. Scand $J$ Infect Dis 2005, 37:306-308.

115. Kylat RI, Ohlsson A: Recombinant human activated protein C for severe sepsis in neonates. Cochrane Database Syst Rev
2006, Issue 2. Art. No.: CD005385. DOI: 10.1002/14651858. CD005385.pub2.

116. Rawicz M, Sitkowska B, Rudzinska I, Kornacka MK, Bochenski P: Recombinant human activated protein $\mathrm{C}$ for severe sepsis in a neonate. Med Sci Monit 2002, 8:CS90-CS94.

117. Green C, Dinnes J, Takeda AL, Cuthbertson BH: Evaluation of the cost-effectiveness of drotrecogin alfa (activated) for the treatment of severe sepsis in the United Kingdom. Int J Technol Assess Health Care 2006, 22:90-100.

118. Abraham E, Laterre PF, Garg R, Levy H, Talwar D, Trzaskoma BL, Francois B, Guy JS, Bruckmann M, Rea-Neto A, et al.: Drotrecogin alfa (activated) for adults with severe sepsis and a low risk of death. $N$ Engl J Med 2005, 353:1332-1341.

119. Haque K, Mohan P: Pentoxifylline for neonatal sepsis Cochrane Database Syst Rev 2003, Issue 2. Art. No.: CD004205. DOI: 10.1002/14651858.CD004205. 